\title{
STUDYING FLOODPLAIN ROUGHNESS IN AN UPPER TISZA STUDY AREA
}

\section{RÓBERT VASS ${ }^{1 *}$, ZOLTÁN TÚR ${ }^{2}$}

Received 8 March 2021, accepted in revised form 7 April 2021

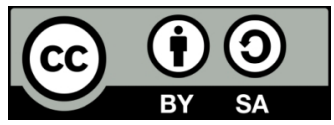

\footnotetext{
${ }^{1}$ University of Nyíregyháza, Institute of Tourism and Geography, Nyíregyháza

${ }^{2}$ University of Debrecen, Department of Physical Geography and Geoinformatics, Debrecen

*Email: vass.robert@nye.hu
}

\begin{abstract}
Floods slowing down due to the significant decrease of the gradient have considerable sediment accumulation capacity in the floodplain. The grade of accumulation is further increased if the width of the floodplain is not uniform as water flowing out of the narrow sections diverge and its speed is decreased. Surface roughness in a study area of 492 hectares in the Upper Tisza region was analysed based on CIR (color-infrared) orthophotos from 2007. An NDVI index layer was created first on which object-based image segmentation and threshold-based image classification were performed. The study area is dominated by land cover / land use types (grassland-shrubs, forest) with high roughness values. It was concluded that vegetation activity based analyses on their own are not enough for determining floodplain roughness.
\end{abstract}

Keywords: roughness, floodplain, Upper Tisza region, NDVI, orthophoto, land use/land cover, object-based image segmentation, image classification

\section{Introduction}

The gradient of the Upper Tisza section between the Ukrainian-Hungarian border and the Szamos mouth is at least two to three times greater than in the lower sections (Gábris et al. 2002; Sándor-Kiss 2006). Due to the large gradient, several record-breaking floods occurred along this section of the Tisza at the turn of the millennium. In addition, the Upper Tisza river is also affected by the dammed Szamos River, which has similar dimensions. For both rivers, water yields exceeding $4000 \mathrm{~m} 3 / \mathrm{s}$ may occur (vizugy. hu). After the flooding of the Tisza in 2001, flood reducing reservoirs were started to be constructed alongside the embankments, the heightening of which had already begun. A reservoir of 58 million $\mathrm{m} 3$ with an average depth of $1.1 \mathrm{~m}$ has been established in the bay of the right bank of Upper Tisza, which has a flood reducing effect of 80-20 cm from Tivadar (705.7 river $\mathrm{km}$ ) to Záhony (627.8 river $\mathrm{km}$ ). The reservoir between the left bank of the Szamos River and the right bank of the Kraszna River, with capacity of 126 million $\mathrm{m} 3$ and an average depth of $2.5 \mathrm{~m}$ can also significantly reduce the flood levels of the Tisza river by holding back the floodwaters of Szamos. As a result of the investments, flood safety has improved considerably, but nevertheless emphasis should be placed on the state of floodplain areas as high-water beds. Large gradient and significant load transport can lead to particularly rapid sedimentation of the floodplain. Especially if 
the hydraulic roughness of the floodplain is high, as dense undergrowth reduces the speed of flowing water and increases accumulation rate (Nagy et al. 2017, Molnár et al. 2017). It is therefore particularly important to be aware of the roughness of the floodplain and its changing conditions (Oroszi-Kiss 2006).

It should be noted that this value is a variable that shows the conditions at the time of the measurement or observation. In the course of the long-term roughness analysis along the Maros river (1953-2000), aerial images recorded at eight dates during the growing season between May and September were used (Oroszi-Kiss 2006). According to the results obtained by visual classification of the patches, their size decreased steadily during the study period, while the hydraulic roughness of the area increased. Based on the above, it is recommended to carry out field surveys of land cover / land use patches defining floodplain roughness - e.g. with global positioning systems (GPS), unmanned aerial vehicle (UAV/UAS), aerial, mobile or ground laser scanning -at the peak of the vegetation cycle. If the data for our analyses are not produced by ourselves, it is worth considering the time of the creation of aerial and/or space remote sensing-based imagery frequently used in surface cover and land use studies in the floodplain and their resolution in time.

A number of examples can be found in the literature of the vectorisation and visual interpretation of various remote sensing data, historical topographic maps on the computer screen in studying floodplain land cover / land use. Pixel or image object-based analyses with semi-automatic or automatic image analysis techniques to identify patches also occur (Bertalan-Szabó 2015; Varga et al. 2015). In this methodological paper, the possibilities of the use of the spectral index layer calculated from aerial remote sensed data (Normalized Difference Vegetation Index, NDVI) in floodplain roughness studies. Furthermore, whether computer screen vectoring and visual interpretation often used in the production of land cover / land use patches - used as basis for the above could be replaced with image object-based segmentation and expert image analysis or not.

\section{Materials and Methods}

The analysis was carried out on the 492 hectares of floodplain study area between the Tisza Bridge (river kilometre 705) connecting Tivadar with Kisar and river kilometre 697 (Fig. 1). The average width of the floodplain on this stretch of the river is 500-700 metres. At the road bridge, the distance between the embankments is only $300-350 \mathrm{~m}$, while the extended floodplain of Szilvás-szeg is about $1800 \mathrm{~m}$ wide. According to the systematic division of natural landscapes, the floodplain area of Tisza on the right handside belongs to the Beregi-Tiszahát microregion of the BeregSzatmár Plain microregion group, and on the left it belongs to the Szamosköz microregion (Csorba et al. 2018). It covers parts of the administrative area of three municipalities: Gulács, Kisar and Tivadar.

The map of the study area (Fig. 1) was created by using QGIS version 3.10.4 (A Coruña). The polygons of the settlements and the polylines of the road network elements were downloaded from OpenStreetMap using the SOFTWARE OSMDownloader module of the software. Flood protection lines were vectorized from othophotos from 2007 (Lechner Knowledge Centre) with the scale of 1:1000 and the river-kilometre signs were vectorised from the georeferenced maps, with the scale of 1:10000 of the Tisza Atlas (Water Science Research Centre 1979) on the computer screen with the scale of 1:4000.

For the roughness analysis of the floodplain, we have downloaded orthophotos taken in 2007 (4 sections), which cover the study area from the spatial data webshop of Lechner Knowledge Centre (geoshop.hu). The following aspects have been taken into account when selecting aerial remote sensing data: 1. remote sensing data made more than 10 years ago are available free of charge; 2 . the time of flight for taking the photos was 


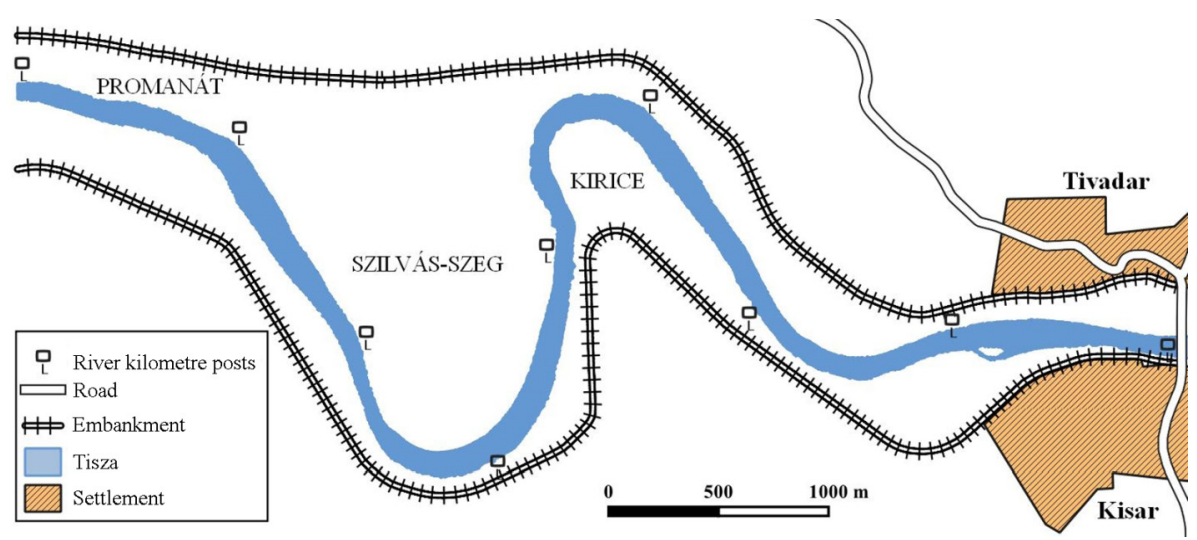

Fig. 1. Location of the study area (based on OpenStreetMap, Volume 5 Tisza, Vízrajzi Atlasz and orthophotos from 2007)

during the growing season; 3. high field resolution; 4. radiometric resolution as high as possible. In orthophotos (Internet 1) with a field resolution of $0.5 \mathrm{~m} /$ pixel taken between July and September 2007, patches of different land cover / land use categories can even be visually interpreted and identified. The 32-bit radiometric resolution allows, for example, the use of different vegetation indices in the analysis.

The preprocessing of orthophotos (making image quality uniform, mosaicing, cutting) and image analysis were made by using SAGA sofver version 7.8. First, an NDVI index layer was created based on the near infrared and red channels of infrared colour files. Object-based image segmentation was performed on this, taking into account the colour characteristics of the pixels. Based on the NDVI average values of the segments, groups were formed and patches in different land cover / land use types were categorised by identifying threshold values (Table 1) and a shadow category was also created. Finally, adjacent segments belonging to the same type were merged and based on them some simple indicators were quantified.

\section{Results}

According to the threshold-based classification of the NDVI spectral index layer, surfaces covered by vegetation with high roughness values (area 171.2 ha, relative area ratio 34.8\%) and forests (136 ha, 27.64\%) dominate (Fig. 2). The latter type of land cover / land use consists primarily of the softwood groves surrounding the Tisza riverbed on both sides, the remnants of hardwood groves, the noble poplar plantations, the navvying forests in the fore front of flood protection embankments and the trees of floodplain orchards.

Table 1. Land cover / land use categories used in the analysis and their roughness value (based on Chow 1959; Németh 1959)

\begin{tabular}{cc}
\hline Floodplain land cover / land use & Roughness value (n) \\
\hline Water surface & 0.025 \\
Surface free of vegetation (arable land, covered) & 0.03 \\
Surface covered with vegetation (arable land, & 0.06 \\
grassland, shrubs) & 0.2 \\
Forest & $?$ \\
Shade & \\
\hline
\end{tabular}




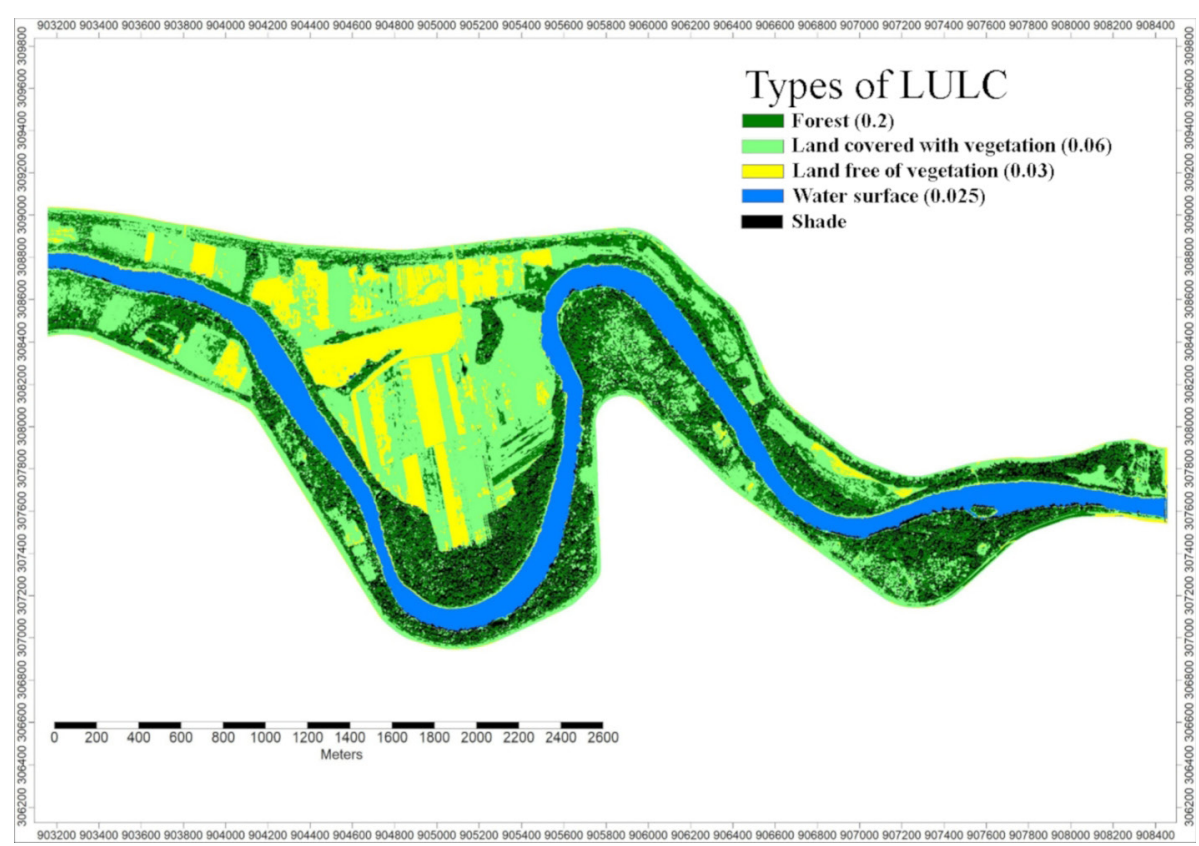

Fig. 2. Spatial pattern of different land cover / land use patches based on image analysis

In our experience, fruit trees and herbaceous vegetation that separates them, or vegetation-free surfaces are commonly classified into the same land cover / land use category (orchard) and drawing them as a single polygon in the course of vectorization and visual interpretation on computer screen. As mosaics with different physical properties have different roughness characteristics, it is better to analyse them independently.

It was difficult to separate arable land covered by different crops, grasslands and bushes-shrubs from each other due to similar NDVI values in the segments; therefore, these mosaics were merged and classified in the same category in the course of image analysis. Unfortunately, the spectral index layer alone did not allow us to include other image characteristics (e.g. shape, texture, topology) in addition to the intensity values of the pixels (vegetation activity). During image object-based segmentation, the use of basic data and other spectral index layer (Enhanced Vegetation Index, EVI) was planned to identify and classify patches of each land cover / land use type as accurately as possible, but the computing requirements of the algorithm exceeded the computing capacity of the available computer.

Due to differences in illumination resulting from variable (high) angles of the position of the Sun in the orthophotos, the area (52.35 ha) and relative area ratio (10.64) of the segments classified as shadow were significant. For these spots, we were unable to clearly determine which land cover / land use types they belonged to, thus we were unable to assign roughness values to them. The shadow effect of the trees on the banks of the river or extending over the riverbed, as well as the structure of the Tisza Bridge at Tivadar, further reduced the already low NDVI values of the water surface segments. The same phenomenon was observed in the case of shade cast by tree canopies in forest strips, tree groups bordering arable lands with bare soil and surfaces covered with herbaceous vegetation of low vegetation activity.

The surface of the Tisza with a low roughness value accounts for $15.46 \%$ (76.06 ha) of the study. Due to similar spectral properties, the separation of artificially covered surfaces and mosaics of vegetation- 
free arable areas was a problem, therefore these segments were also merged into one category. The area of begetation-free surfaces is 56.37 ha with a relative area ratio of $11.46 \%$ in the time horizon of the analysis.

\section{Discussion}

Object-based image segmentation of the NDVI layer mostly creates small segments with a few pixels. In most cases, these cannot be considered really existing objects or landforms. By merging adjacent segments of pixels with similar intensity, image objects or object-like features (e.g. canopies of tree individual) could be formed that have their own meaning and can be interpreted as land cover / land use patches in floodplain roughness studies. Computer screen vectorization and visual interpretation, which are time consuming and rely too much on user subjectivity can be replaced as a whole or in part by object-based image segmentation and automatic image analysis procedures, however, one spectral index layer alone is generally not sufficient to determine the pattern of land cover / land use in the floodplain and to study the roughness of the floodplain.

\section{Acknowledgements}

The research was supported by project EFOP-3.6.116-2016-00022. The project was supported by the European Union and co-financed by the European Social Fund.

\section{References}

Bertalan L. - Szabó G. (2015): Mederfejlődési vizsgálatok a Sajó hazai szakaszán. (Investigations of river bank development on the alluvial Sajó River of Hungary.) In: Boda J. (ed.) Az elmélet és a gyakorlat találkozása a térinformatikában: Térinformatikai Konferencia és Szakkiállítás VI. (Theory meets practice in GIS.) Debreceni Egyetemi Kiadó, Debrecen, 61-68.

Chow V.T. (1959): Open-channel hydraulics. McGrawHill, New York, 89-127.

Csorba P. - Ádám Sz. - Bartos-Elekes Zs. - Bata T. -
Bede-Fazekas Á. - Czúcz B. - Csima P. - Csüllög G. - Fodor N. - Frisnyák S. - Horváth G. - Illés G. - Kiss G. - Kocsis K. - Kollányi L. - KonkolyGyuró É. - Lepesi N. - Lóczy D. - Malatinszky Á. Mezősi G. - G. - Molnár Zs. - Pásztor L. - Somodi I. - Szegedi S. - Szilassi P. - Tamás L. - Tirászi Á. - Vasvári M. (2018): Tájak. (Landscapes.) In: Kocsis K. - Horváth G. - Keresztesi Z. Nemerkényi Zs. (eds.) Magyarország nemzeti atlasza 2. kötet. Természeti környezet. (National Atlas of Hungary. Volume 2. Natural environment.) MTA CSFK Földrajztudományi Intézet, Budapest, 279-286.

Gábris Gy. - Telbisz T. - Nagy B. - Belardinelli E. (2002): A tiszai hullámtér feltöltődésének kérdése és az üledékképződés geomorfológiai alapjai. (Upsilting of the floodplain of the River Tisza and the geomorphologie basis of the formation of deposits.) Vízügyi Közlemények (Hydraulic Egineering) 84(3), 305-322.

Molnár G. - Scholtz A. - Vass R. (2017): Accumulation studies at specific sampling areas of the active floodplain in the Upper-Tisza region. Acta Geographica Debrecina Landscape And Environment 11:, 14-22.

Nagy J. - Fiala K. - Blanka V. - Sipos Gy. - Kiss T. (2017): Hullámtéri feltöltődés mértéke és árvizek közötti kapcsolat az Alsó-Tiszán. (Connection between floodplain aggradation and floods on the Lower Tisza, Hungary.) Földrajzi Közlemények (Geographical Review) 141 (1), 44-59.

Németh E. (1959): Hidrológia és hidrometria. (Hydrology and hydrometry.) Tankönyvkiadó, Budapest, 179-210.

Oroszi V. Gy. - Kiss T. (2006): Területhasználatváltozás a Maros egy hullámtéri öblözetében a XIX. századtól napjainkig. (Landuse changes on the floodplain of River Maros since the XIX. century.) Tájökológiai Lapok (Journal of Landscape Ecology.) 4 (2), 309-316.

Sándor A. - Kiss T. (2006): A hullámtéri üledékfelhalmozódás mértékének vizsgálata a Közép- és az Alsó-Tiszán. (Flood plain sedimentation rates along the Middle-and Lower Tisza reaches.) Hidrológiai Közlöny (Hungarian Journal of Hydrology) ( 86 (2), 58-62.

Varga K. -Szabó Sz. -Szabó G. - Dévai Gy. - Tóthmérész B. (2015): Improved land cover mapping using aerial photographs and satellite images. Open Geosciences 7 (1), 15-26.

Vízgazdálkodási Tudományos Kutató Központ (1979): Vízrajzi Atlasz (Hydrology Atlas) sorozat 22. Tisza 5. kötet Záhony-Tiszabecs (628-705 fkm). Budapest, $82 \mathrm{p}$. 
Internet references

http://www.ftf.bfkh.gov.hu/portal/index. php/termekeink/legifelvetelek (time of download: October 2020) 